\title{
Lazarillo de Tormes and Rhetorical Paradox
}

\author{
Robin McAllister \\ Sacred Heart University, Fairfield, Connecticut, USA
}

\begin{abstract}
Picaresque novel as a genre is usually traced back to the anonymous Lazarillo de Tormes, but mystery surrounds the origin of this paradoxical narrative that appeared in 1554. In particular, the techniques of irony and paradox employed in Lazarillo as vehicles for moral and social satire are influenced by an extremely widespread classical tradition, the rhetorical paradox, recently revived and made popular by Erasmus in his Praise of Folly. Lazarillo's ties with a humanist revival of literary genres suited to social satire and self-inquiry extends to other forms of Menippean satire of which the rhetorical paradox and mock oration are only specialized forms. The Golden Ass by Apuleius, a 2nd Century A.D. prose Menippean satire, alluded to in Cervantes’ Don Quixote, and Lazarillo both employ a frame-story motif, "the servant of many masters," as a vehicle for social and moral commentary. A fundamental conflict between how people appear and what in fact they are runs through the narrative, first exemplified by Lazaro's clever exposure of others, then extended to Lazaro himself. Paradox extends from Lazaro himself and his actions to the very form and style of the narrative itself. In Paradoxia Epidemica: The Renaissance Tradition of Paradox, Rosalie Colie traces the influence of rhetorical paradox through the literatures of the 16th and 17th century. Rhetorical paradox is a formal defense of an unexpected, unworthy, or indefensible subject, as in Erasmus’ mock encomium of folly. Rhetorical paradox criticizes and calls into question traditionally received opinion by appearing to assert one position while in fact asserting another by implication. By placing his praise in the mouth of the subject itself of that praise, the praise of folly in the mouth of Folly in Erasmus, or the praise of Lazaro the self-made man in the mouth of Lazaro, the satirist ironically undercuts the reliability of the speaker and removes all objective standards by which the discourse can be measured. Lazaro's self-justification is as duplicitous and unreliable as Folly's self-praise of folly or the ancient paradox of the Liar: "Epimenides the Cretan said, 'All Cretans are liars."” The ultimate function of irony and paradox in rhetorical paradox is to stimulate in the reader a process of self-examination and reflection. Lazarillo appears to have been written by a trained humanist, and, further, a humanist familiar with Menippean satire, whether the dialogues of Lucian, the prose satire of Apuleius, or rhetorical paradox as a vehicle of moral and social satire.
\end{abstract}

Keywords: rhetorical paradox, Menippean satire, Lazarillo de Tormes

\section{Introduction}

Picaresque novel as a genre is usually traced back to the anonymous Lazarillo de Tormes, but mystery surrounds the origin of this paradoxical narrative that appeared in 1554, published separately in three different cities, Alcala de Henares, Burgos, and Antwerp. Theuthor is unknown, his reasons for anonymity, or the literary 
precedents, if any, he followed. The Alcala edition hints at an anterior one, but no ur-Lazarillo has ever come to light. Indeed, the small book appears to have precedent, save in folk motifs, but to have sprung into existence sui gener is without the intervention of human authorship or the sustaining hand of a familiar literary tradition. If, as if generally conceded, the anonymous author was a trained humanist, where is the evidence in Lazarillo of a humanist revival and imitation of classical genres and tradition? Or, are there indeed certain genres, recently revived by Erasmus and others, hidden from explicit awareness, deliberately left implicit by the author, that in fact contribute to Lazarillo's form and effect? In particular the techniques of irony and paradox employed in Lazarillo as vehicles for moral and social satire are influenced by an extremely widespread classical tradition, the rhetorical paradox, recently revived and made popular by Erasmus in his Praise of Folly.

This is not to say that Lazarillo is limited to the genre of mock oration. Lazarillo's ties with a humanist revival of literary genres suited to social satire and self-inquiry extends to other forms of Menippean satire of which the rhetorical paradox and mock oration are only specialized forms. Traditionally classified as a picaresque novel, Lazarillo in fact cannot be unqualifiedly classed within any one single genre, whether realistic novella, epistle, or confessional autobiography. Rather, it embraces a mixture of genres and styles as is characteristic of Menippean satire.

\section{Rhetorical Paradox}

This article will concentrate on the influence of rhetorical paradox, but the 2nd Century A.D. prose Menippean satire, The Golden Ass by Apuleius, alluded to in Cervantes’ Don Quixote, must be mentioned in passing. In both the Golden Ass and Lazarillo, the authors employ a frame-story motif, the servant of many masters, as a vehicle for social and moral commentary. Apuleius's pseudo-autobiography uses the wanderings of the author, transformed from his properly human form into that of a beast, to expose the underside of society that each member of the social hierarchy strive to keep hidden from public view. These wanderings provide the precedent for Lazarillo's narrative structure.

In Paradoxia Epidemica: The Renaissance Tradition of Paradox, Rosalie Colie traces the influence of rhetorical paradox through the literatures of the 16th and 17th century. Rhetorical paradox is a formal defense of an unexpected, unworthy, or indefensible subject, as in Erasmus' mock encomium of folly. Frequently it is a defense of a position officially disapproved in public opinion, as, for example, Lazaro's assertion at the end of his prologue addressed to a well-born reader that nobility of worth is superior to nobility of birth. Rhetorical paradox criticizes and calls into question traditionally received opinion by appearing to assert one position while in fact asserting another by implication. The speaker attributes certain received opinions to his audience and then challenges this conventional wisdom by holding forth an alternative or competing view. For example in Lazarillo the traditionally accepted opinion that cuckoldry is a dishonor, not a proper basis for social respectability. The author asserts one position through the mouth of Lazaro himself, while implying another through his own deliberate anonymity. Moreover, by placing his praise in the mouth of the subject itself of that praise, the praise of folly in the mouth of Folly in Erasmus, or the praise of Lazaro the self-made man in the mouth of Lazaro, the satirist ironically undercuts the reliability of the speaker and removes all objective standards by which the discourse can be measured. The ironic reversals and undercutting of rhetorical paradox forces the reader to re-evaluate not only the received opinion the speaker calls into question, but the very basis upon which criticism 
is made. Both positions, the heterodox and the orthodox, are made to undercut each other in contradictory ways.

Many critics have commented on irony and paradox in Lazarillo without relating these techniques of the humanist revival of rhetorical paradox. In Lazaro's prologue to his tale, his vainglorious desire for fame and praise contasts sharply with the anonymity of the author himself. Lazaro addresses himself to a nobleman, promising to put down the events of his life in writing as an example to the well-born reader of the true nobility of the self-made man who has risen to social respectability without the benefit of good fortune and birth. The reader is startled to discover at the end of Lazaro's story that social respectability for him consists of sharing his wife with the Archpriest of Sant Salvador in order to ensure Lazaro's continued prosperity. Lazaro has purchased his material well-being at the price of spiritual suicide. Although Lazaro's account appears at first to be motivated by the Socratic injunction, Know thyself, Lazaro, the keen observer and critic of other hypocrites, intentionally blinds himself to his wife's infidelity and calls it honor and domestic tranquility.

A fundamental conflict between how people appear and what in fact they are runs through the narrative, first exemplified by Lazaro's clever exposure of others, then extended to Lazaro himself. Although he appears to criticize social conformity at the beginning of his narrative, by the end he is playing the social conformist. Nor are these the only paradoxes and reversals. There is a reversal in Lazaro's own moral character and situation in the third tractate, where he takes pity on his own master, the starving squire, and supports him through his begging. In the first tractate Lazaro had learned to out-trick the master trickster himself, the blind man who gave Lazaro his first lessons in getting ahead. In the second tractate Lazaro reverses customary expectations by praying not for the recovery of the dying but for their demise, so that he can draw life through the occasional largess of the funeral feasts. Until he meets the squire, Lazaro suffers as a victim of his masters whom he must outwit and escape from in order to live. But in the third tractate his moral relationship to his masters is inverted. Lazaro comments that his bad luck has turned everything upside-down. Instead of escaping from his master, his master runs out on him. After the incident with the squire, Lazaro's fortunes begin to improve materially but deteriorate morally. The narrative runs through the brief episode with the friar, the false testaments, false penances, and false miracles of the pardoner, to his eventual appointment as town crier and his subsequent marriage to the Archpriest's mistress. Ironically, in his capacity of town crier, he must publish the secret misdeeds of condemned men, though he is now incapable of admitting his own misdeeds. His willful self-deception is a total reversal of his earlier astute criticism of the poor squire's social pretense and hypocrisy. He is revealed to the reader at last as the trickster tricked by his own wife, able to publish the faults of others, but blind to his own.

Paradox extends from Lazaro himself and his actions to the very form and style of the narrative itself. Lazarillo is a work of fiction presented to the reader as a true autobiography, an epistle, though written, as oral in tone. The narrative appears both incomplete and episodic on the one hand and highly unified and self-referential on the other. Its style is both natural and artificial, apparently colloquial, but rich in rhetorical devises and classical allusions. The use of language is constantly duplicitous: it serves to hide and deceive as much as reveal. In his prologue Lazaro echoes an epic formula, promising the reader "remarkable things never seen or heard before.” The narrative is not an epic, however, but the very opposite. The guileless surface of Lazaro's words is illusory; they hide a secret malice and pride. Lazaro is applying lofty epithets to what would conventionally be considered a dishonorable life. The reader is asked to regard his dubious career as exemplary, but hardly exemplary of traditional ideals and values considering the true nature of his self-proclaimed honor. 
In Lazarillo the techniques of irony and reversal belong to the genre of rhetorical paradox. Lazarillo differs significantly from subsequent picaresque novels in refusing to allow the reader to gaze down with self-assured contempt on the targets of satire-or upon Lazaro himself-from a position of moral superiority. If the reader shares the conventional assumptions of the nobleman to whom Lazaro dedicates his narrative, the reader is placed in a paradoxical position by the end of the narrative, when the reader realizes that Lazaro's own actions have undercut his claim to honor. Insofar as the reader sympathizes with Lazaro, the reader implicitly shares his criticism of the very social hierarchy and status quo of which the reader is a part. Insofar as the reader disapproves of Lazaro, the reader risks the charge of pointing to the mote in Lazaro's eye without perceiving the mote in the reader's own. No one in this curiously ironic narrative can point a finger at anyone else from an unimpeachable position of moral authority. The author, by choosing to remain anonymous, has refused to assert his own opinion as authoritative and to exempt the reader from the critical necessity to know thyself. The reader Lazaro assumes is presumably a part of that imperial Spain whose rise to eminence Lazaro equates with his own dubious fortune at the end of the narrative. If Lazaro is indeed exemplary of the Spain of Charles V, the reader is forced to re-examine the grounds of the reader's own assumptions of moral and social respectability. The anonymous author criticizes the way his contemporary Spain has risen to material power by allowing an exemplary figure of that rise, the self-made man, to sing his own praises in such a way that a cautious reader is alerted to the moral bankruptcy of the new values without blinding himself to the shortcomings of the old society Lazaro so astutely calls into question. The model for this form of satire is the rhetorical paradox, an antique literary tradition enthusiastically revived by Renaissance humanists and made fashionable by Erasmus' Praise of Folly.

In order to deliver a paradoxical encomium it is not necessary that the orator believe in the argument he advances. He may choose to remain anonymous and place his assertions in the mouth of his character, undercutting these assertions through irony or through the progressive revelations and reversals of narrative action. It is necessary, however, that the audience, representing received opinion, believe in the dialectical opposite of what the character assets. Erasmus' mock oration would be neither surprising nor paradoxical if the audience did not conventionally assume that folly is something to be avoided rather than praised. Similarly, Lazaro's defense of his social respectability would not be unexpected or remarkable if the reader did not assume that the deceit and struggle of a poor beggar boy were far removed from the social respectability the reader takes for granted. By explicitly arguing one position while attributing its opposite to the audience, the satirist is capable of double ironies. Cicero in his Paradoxa Stoicorum by presenting a praise of virtues in the form of a paradox implies that his audience is so corrupted that traditional values are no longer received opinion that can be taken for granted.

Similarly, in Lazarillo by attributing honor and respectability to self-deceit, hypocrisy, and vain-glory, the anonymous author forces the reader to examine whether the reader's own claims to honor are better founded than those of the self-proclaimed exemplary figure of that society. The reader dares not condemn Lazaro without first examining the moral authority of the reader's position. The reader cannot admire Lazaro without calling into question the social hierarchy and social conventions Lazaro attacks and exposes to ridicule, nor can the reader condemn Lazaro without the risk of hypocrisy. Are Lazaro's moral compromises with personal integrity for the sake of social appearances indeed something the reader is not only familiar with but practices in the reader's own life? Improbable as it first appears, does Lazaro’s cynical opportunism in fact represent the true moral and social 
condition of the imperial Spain of Charles V? In pointing a finger disapprovingly at Lazaro, is the reader not in fact pointing a finger at himself? By refusing the explicitly assert his own moral position by remaining anonymous and ironically undercutting Lazaro's words with the evidence of his actions, the author forces the reader to evaluate Lazaro's story by applying its paradoxical assertions to the reader and engaging in an effort of self-criticism, though the alternative of willful moral blindness is always available if the reader complacently follows Lazaro's own example rather than reflecting on the author's implied criticism.

Lazaro's account of himself does not employ the formal conventions of mock oration as explicitly as does Erasmus' Praise of Folly. Nevertheless, the prologue through its duplicitous use of the exordium, the false modesty trope, sententiae, and other conventions of epidectic oratory invites the reader to consider the narrative in terms of a formal defense of an indefensible or conventionally unworthy subject. Indeed, as the reader reflects on the implicit irony of Lazaro's vainglorious desire for fame in sharp contrast to the author's deliberate anonymity and gradually discovers the dichotomy between Lazaro's words and actions, Lazaro's self-justification is as duplicitous and unreliable as Folly's self-praise of folly or the ancient paradox of the Liar: “Epimenides the Cretan said, 'All Cretans are liars.'”

The ironies and paradoxes of Lazarilloexhibit two important characteristics of rhetorical paradox, however, that do not require the formal divisions of mock oration. In the first place, a defining characteristic of rhetorical paradox is that by defending a position contrary to received opinion, the orator calls into question values and traditions previously taken for granted. The second point relates the ultimate function of irony and paradox to the aim of stimulating in the reader himself a process of self-examination and reflection. The constant ironic undercutting of positions put forth by Lazaro functions to remove an objective or authoritative point of reference by which the discourse can be judged. One assertion or position seems balanced or qualified by another. The author by his deliberate anonymity in effect refuses to assert his own opinion as authority and instead allows his character to praise and condemn himself with his own words. The central paradox in Lazarillo, the ironic reversal that most suggests the influence of rhetorical paradox, is the discovery that after exposing the moral blindness and hypocrisy of others, Lazaro in turn blinds himself to his wife's infidelity and calls his cuckoldry social respectability. This ironic undercutting of Lazaro's previous warning to the reader that many recoil from the faults of others without perceiving similar faults in themselves forces the reader to re-examine the reader's own assumed values for signs of self-deception and hypocrisy. If the arch-trickster himself can be tricked by his wife, if the critic of social pretensions can sacrifice personal integrity to an appearance of honor, what risks does the reader run? The reader must apply Lazaro's example to himself before the reader hastily points a finger of approval or disapproval at Lazaro. In fact, in pointing a finger at Lazaro, is the reader not pointing a finger at himself, in the best tradition of paradox?

\section{Conclusion}

Lazarillo appears to have been written by a trained humanist, and, further, a humanist familiar with Menippean satire, whether the dialogues of Lucian, the prose satire of Apuleius, or rhetorical paradox as a vehicle of moral and social satire. Erasmus' Praise of Folly revived and promoted the techniques of rhetorical paradox, while the works of Lucian and Apuleius influenced the episodic, narrative satires of a variety of writers, including Cervantes. Lazarillo, the father of the picaresque novel, has its own origin in the renewed interest among 
humanists in forms of Menippean satire. This genre of satire is characterized in turn by its ability to accommodate a variety of genres and a mixture of styles. Lazarillo resists easy generic classification, exhibiting the features of mock oration at one point, of confessional autobiography, epistle, or mock epic at another. This tendency to embrace several genres defines the decorum of Menippean satire. Even the abrupt, seemingly arbitrary conclusion of Lazarillo conforms to the expectations of this genre. Speaking in reference to Erasmus' Praise of Folly, Colie writes: "A formal aspect of the end of this encomium — and of many others in the genre-is that it has no formal ending. The discourse stops, certainly, but in such a way as to stimulate further thought in the reader, even further speculation—Folly cuts off her own discourse, but not discourse in general” (Colie, 1966, pp. 20-1). If this paper's speculations about Lazarillo de Tormes, the influence of rhetorical paradox, and Menippean satire stimulate further speculation, it will serve its purpose, whether or not it convinces with its conclusions.

\section{References}

Colie, R. (1966). Paradoxia epidemica: The Renaissance tradition of paradox. Princeton, NJ: Princeton University Press. Lazarillo de Tormes and El Abencerraje. (1966). Claudio Guillen. (Ed.). New York, NY: Dell.

Two Spanish picaresque novels: Lazarillo de Tormes, Anon., The Swindler, Francisco de Quevedo. (1969). Michael Alpert. (Trans.). Baltimore, Maryland: Penguin. 